\title{
Review of Design Techniques Applied to Electrical Installation Projects: a Comparison of CAD and BIM Tools
}

\author{
Revisão de Técnicas de Desenho Aplicadas em Projetos de \\ Instalações Elétricas: uma Comparação entre as Ferramentas \\ CAD e BIM
}

DOI: 10.54019/sesv3n1-029

Recebimento dos originais: $15 / 01 / 2022$

Aceitação para publicação: 10/02/2022

\begin{abstract}
Leonardo Nery Carrijo dos Santos
Incomplete Higher Education

Institution: Universidade Federal de Uberlândia (UFU)

Adress: Av. João Naves de Ávila, 2121 - Uberlândia - MG

E-mail: leonardoncsantos@gmail.com

\section{Cibelly Cristina Rodrigues Couto}

Incomplete Higher Education

Institution:Universidade Federal de Uberlândia (UFU)

Adress: Av. João Naves de Ávila, 2121 - Uberlândia - MG

E-mail: cibellycristinaudi@gmail.com
\end{abstract}

\begin{abstract}
In various sectors and industries, the use of digital design drawings has enabled the collection and visualization of relevant job data. The emergence of the CAD system changed several branches of the design segment and until today it is one of the main methods used. However, the evolution of society and technology culminated in the development of the BIM methodology, seen by many as promising in the design of projects, as it allows graphic improvements while integrating the project participants in the different phases of the work. Such an approach becomes information focused by exploring parametric and 3D representations of virtual models. In this article, both CAD and BIM contributions to the industry are raised through a case study of a residential electrical project developed by the company CGWorks.
\end{abstract}

Keywords: autocad 2d, revit. electrical installations, cad. bim.

\section{RESUMO}

Em diversos setores e indústrias, a utilização de desenhos de projetos digitais permitiu o levantamento e visualizam de informações relevantes da obra. $O$ surgimento do sistema CAD alterou diversos ramos do segmento de projetos e até hoje é um dos principais métodos utilizados. Entretanto, a evolução da sociedade e tecnologia culminou no desenvolvimento da metodologia BIM, vista por muitos como promissora na concepção de projetos por possibilitar melhorias 
gráficas ao mesmo tempo que integra os participantes do projeto nas diversas fases da obra. Tal abordagem de trabalho passa a ser focada na informação ao mesmo tempo que explora representações paramétricas e 3D de modelos virtuais. No presente artigo, as contribuições de ambas as tecnologias CAD e BIM são levantadas por intermédio de um projeto de instalações elétricas residencial elaborado pela empresa CGWorks.

Palavras-chave: autocad 2d, revit, instalações elétricas, cad, bim.

\section{INTRODUCTION}

Since the search for symmetry and accuracy applied to engineering during the Renaissance period to the technological advances of the 20th century resulting from world conflicts, new methods of project representation were added to the Architecture, Engineering and Construction (AEC) industry in order to respond to the different demands imposed by the market in each period [1]. In this way, the relevance of CAD methodology is observed in the last decades, since it allows the conception of digitalized projects with precision and efficiency.

Once employed, CAD technology usually provides agility and efficiency in project execution, thus enabling the storage of important construction information, besides integrating all the agents that participate in the process at different stages. In this sense, it is noteworthy that, according to professionals in the construction sector, when the different stakeholders cannot communicate effectively, up to $30 \%$ of the total project value can be wasted [2]. Thus, as a result, the methodology of creating virtual BIM models emerged since, besides the three-dimensional modeling already present in several CAD tools, this methodology allows the generation of parameterized objects with associated attributes in an integrated and collaborative platform [3].

As [4] points out, it is worth mentioning that some countries are already examples in the adoption of this methodology, such as the United Kingdom and Singapore, while others, like the United States and the Netherlands, already require BIM in projects funded by the government. Thus, motivated by the global trend that BIM is a positive instrument for the AEC industry, the Brazilian Federal Government issued Decree 10306/2020 on April 2, 2020. This document establishes, finally, the duty of using BIM in the development of architecture and engineering projects in federal public works and services that begin in 2021 . With 
this determination, it is expected that the use of BIM will be increasingly spread not only to other federal institutions but also to companies in the private sector.

Thus, the objective of this research is to demonstrate the benefits and challenges that BIM methodology presents in the area of electrical installations, since this is the least developed in terms of solutions available in the market, as suggested by [5]. To this end, the article is divided so that the first topic contains the theoretical definition of CAD and BIM methodologies, along with their characteristics in project compatibilization. Subsequently, there is a case study about a residential electrical project in which a comparative analysis of the aforementioned tools was performed.

\section{PROJECT REPRESENTATION AND MODELING METHODOLOGIES}

As observed in [6] and [7], in the last decades, the AEC industry has been changing, since the construction execution processes are increasingly complex and interconnected, such that more robust and intelligent tools are required in the course of the project. In this sense, as observed in [7], technologies have begun to emerge that link the digital artifacts of a construction in a collaborative environment of data representation and visualization. Such methodology is usually linked to the acronym BIM.

\section{CAD TECHNOLOGY}

It can be observed in [8] that, since the middle of the twentieth century, the conventional methods and artifacts of project development, usually linked to representations on drawing boards, have been gradually replaced by solutions based on CAD technology, enabling designers to widely digitize the assets related to the project in two or three-dimensional schemes. Thus, it is considered that the AEC industry obtained a relevant gain in terms of flexibility, optimization and precision [7][8].

Analogously, as pointed out by [6], the ability of CAD software to represent projects in two or three dimensions allows the designer greater assertiveness for different types of assets. For hydraulic, electrical, and architectural design, for example, the use of Autodesk AutoCAD 2D CAD software is commonly sufficient [6]. Similarly, for modeling parts or artifacts where greater precision and detail are 
desired, Autodesk AutoCAD 3D software is usually chosen [6].

However, it is worth noting, as suggested by [8], that the technology that guides contemporary engineering systems is commonly aligned with objectoriented programming, data analysis, and interoperability between platforms. In this sense, it is observed that, although CAD has improved the systems of visualization and representation of building projects and equipment modeling, there has not been, in fact, a paradigm shift in terms of workflow. It can be seen in Figure 1, for example, that the execution of tasks on CAD platforms occurs in a linear and individualized way. Therefore, the eventual need for changes in the project may result in realimentations in other execution disciplines.

Figure 01: Workflow of a CAD project.

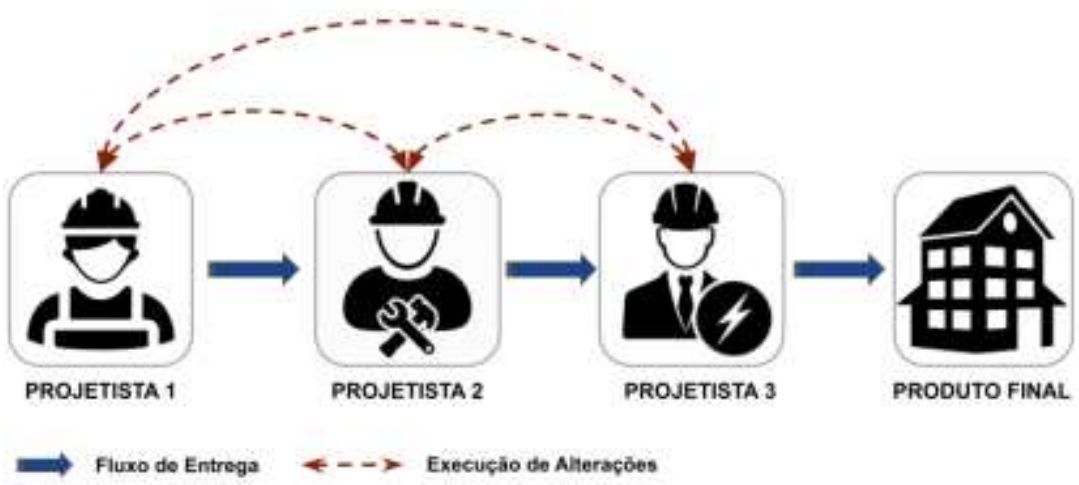

Source: The author.

\section{BIM METHODOLOGY}

Developed over the past few years, the BIM methodology aims to meet the new demands of the market from a multidimensional modeling, i.e., that brings together both quantitative and qualitative data of assets in a single solution, allowing time and cost estimates, conflict detection and decision-making in a more integrated and collaborative work environment [8].

Thus, the application of BIM methodology in the AEC industry can represent a paradigm shift as well as a workflow change $[7,8]$. In such a perspective, the project is developed in a coordinated manner in a single platform, such as Autodesk Revit software, for example, in which the different disciplines of a building are developed separately, but integrated in the final solution [8].

To this end, BIM design ensures compatibility among the various designers 
as an initial execution requirement, and not as a process performed at each change of work sphere, as shown in Figure 1, in the CAD approach. Therefore, the BIM design environment allows the exchange of information between designers in real time as well as the fast and coordinated execution of each discipline's tasks, as seen in Figure 2.

Figure 02: Workflow of a BIM project.

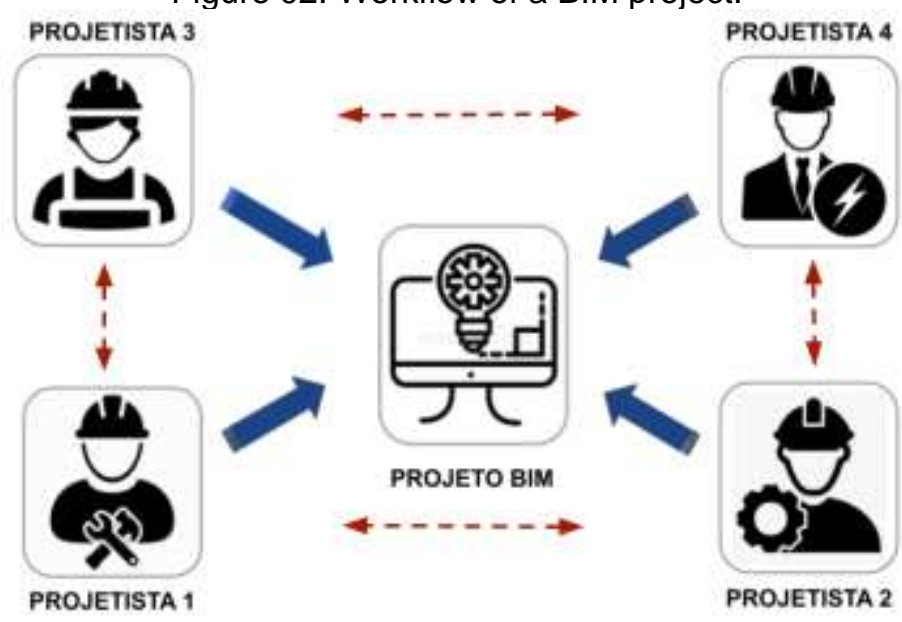

Source: The author.

\section{CASE STUDY}

Although in recent years specialized tools for specific engineering sectors have been created and adopted by new professionals, today there is still a strong tradition of using CAD tools in the preparation of electrical installation projects. Once the processes are well defined, many companies do not see the real advantages of migrating to BIM software, since this change demands a high investment in relation to implementation, training and adaptation of employees. In addition, such a change requires caution so that this transition is safe and presents few risks in terms of the dimensioning of electrical projects, since in some cases it is necessary to modify some configurations of the tool, adapting them to the norms of the Brazilian Association of Technical Norms (ABNT).

However, exploring BIM tools can result in significant advantages that corroborate to the success of electrical projects, thus reducing costs by up to $20 \%$ [9] and up to $40 \%$ of unanticipated budget changes, as shown in a research conducted by Stanford University Center for Integrated Facilities Engineering 
(CIFE) [10]. In addition, the new workflow allows collaboration between designers of the various disciplines involved through interoperability.

For the case study, we used the electrical design of a residence prepared by the company CGW in AutoCAD 2D software, supported by the Visual Electric tool, which was developed by the institution itself, and Revit that uses the BIM concept. Initially, it was found that one of the main differences between them is the attribution of parameters to the elements. While AutoCAD 2D draws lines, symbols and other geometric representations to represent the components, distinguishing them mainly by interpreting legends and notes, in Revit the designer directly inserts items with pre-defined parameters, which are recorded characteristics such as voltage and power, for example. These elements are called families, which can be generic, based on commercial standards or customized with data according to norms and standards used by the company itself.

Because of the use of Visual Electric for this specific project, the parameters were not a problem, since it has its own library with items needed for electrical projects, along with the option to change their attributes, as can be seen in Figure 3.

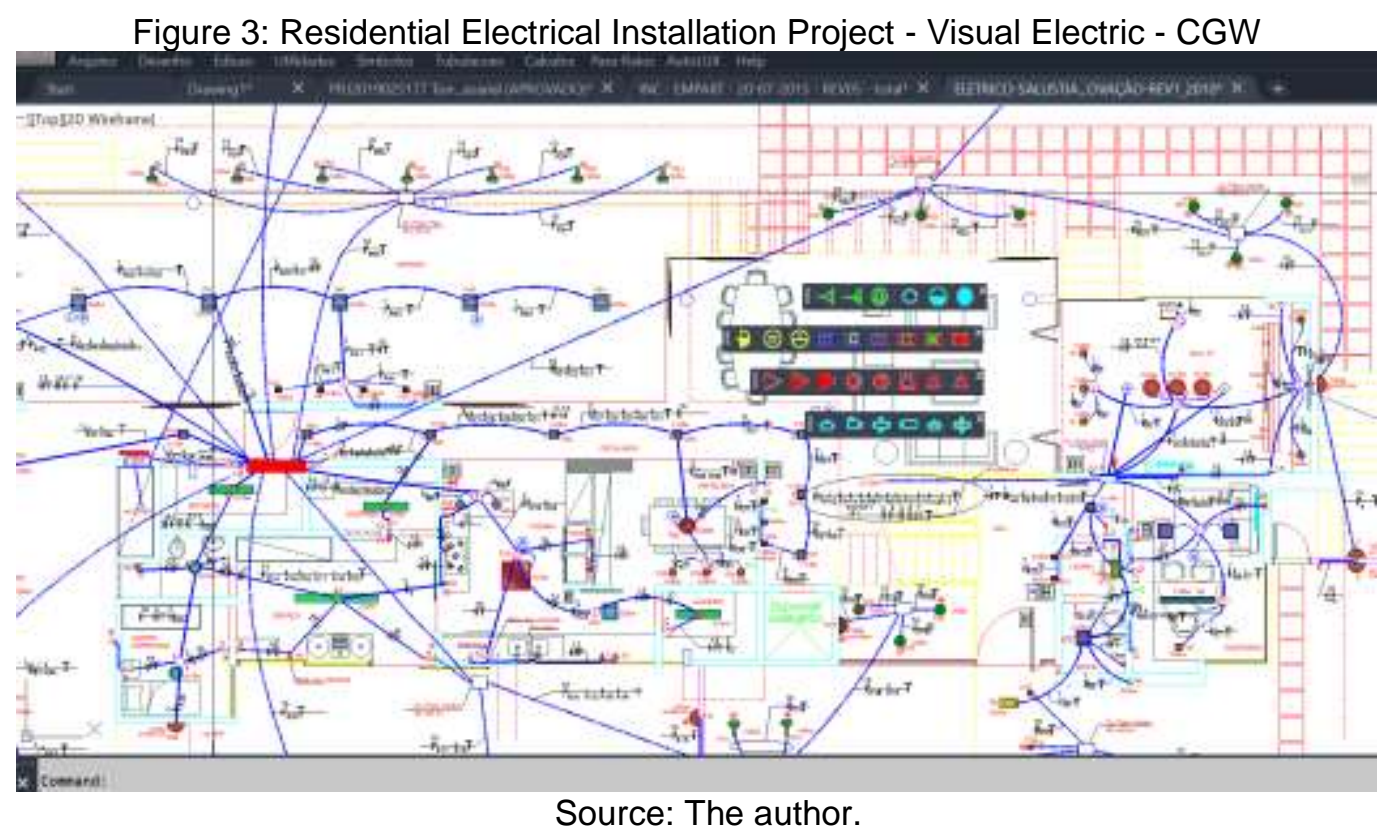

Considering that one of the main impasses of a project are the unforeseen changes that are made during its elaboration, Revit proved to be an effective tool 
in solving this problem, since the modifications are updated automatically and are visible to all members instantly. On the other hand, in AutoCAD software changes must be communicated and a new version of the work must be generated and sent to the other designers involved, making it difficult, consequently, to identify possible new incompatibilities.

Moreover, in Revit 2021 an electrical circuit is generated automatically when connecting light fixtures and sockets to a power distribution equipment and its numbering is performed obeying the sequence of loads, and can be modified according to the user's needs. In contrast, in AutoCAD the circuits must be indicated manually.

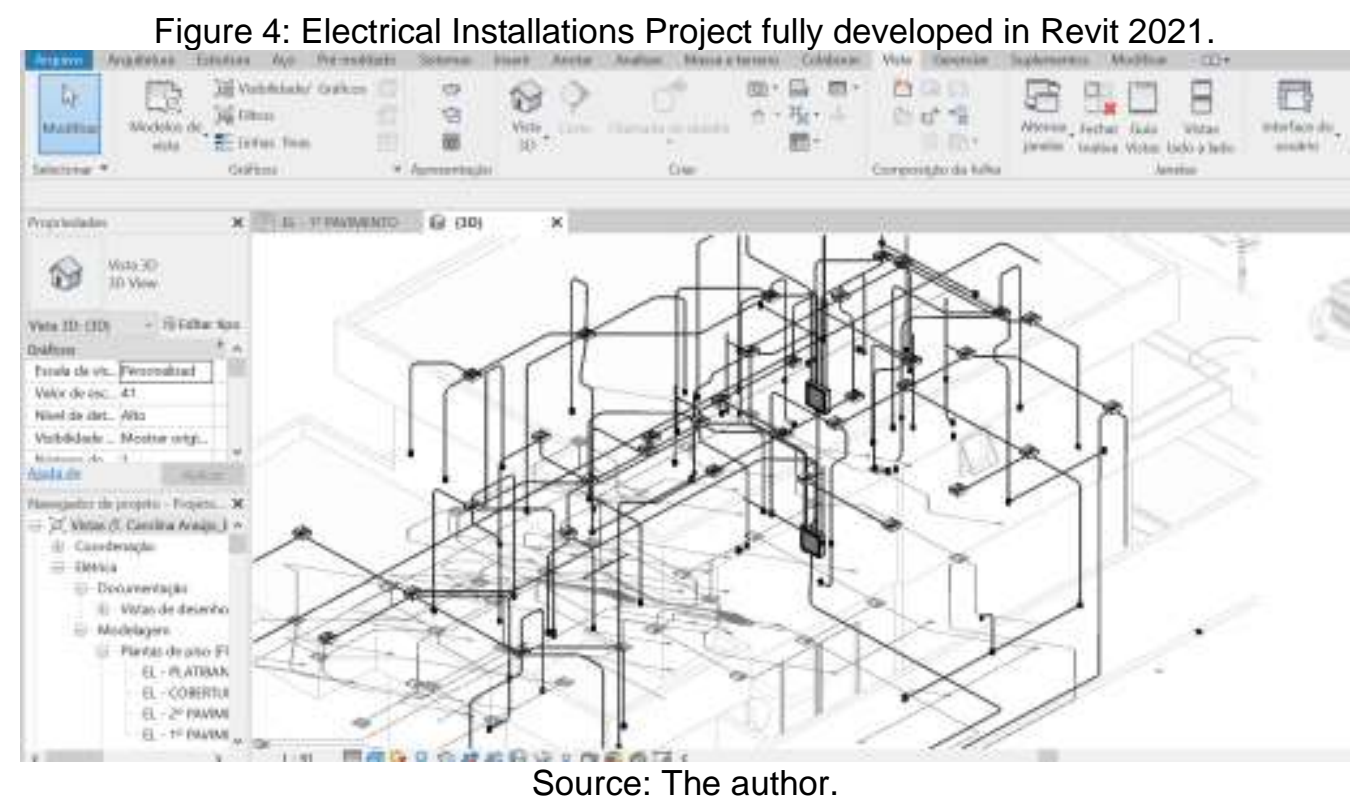

Similarly, two- and three-phase connections can be made in Revit according to the two- or three-pole configuration of the equipment. Every family that has a connector has simultaneously the function of electrical connection, which allows you to assign all the essential electrical characteristics for the calculations that can be performed later.

Finally, after inserting and configuring all the elements in the project, the software allows the generation of numerous tables, be they related to the dimensioning of the components, bill of materials, construction details, budget, among others. Such functionality allows for increased project reliability, safety, and accuracy, directly implying an increase in productivity. In addition, as seen in 
Figure 4, Revit enables the generation of load charts, lighting calculations, and circuit generation, among other functions. In the AutoCAD system, on the other hand, the generation of the load diagram was only possible thanks to Visual Electric. At this stage, it is essential that all information is appropriate, thus ensuring the correct operation of all elements present in the project.

\section{CONCLUSION}

Although there are parallels between CAD and BIM, both present different proposals. In the electrical field, CAD deals almost exclusively with the process of creating models and floor plans. This is also an important part of BIM, but BIM includes much more than its designs. This is an innovative and promising concept that is revolutionizing the design industry, providing an ever-increasing integration of information.

From the analysis performed it is possible to conclude that using Revit for the electrical sector can bring many advantages, especially for its efficient interoperability and functions that allow better project organization and time savings. However, such migration requires caution since, if designers do not have the necessary skills in handling the tool, the level of complexity in project design may be even higher as opposed to a CAD tool, making this not an effective applicability. 


\section{REFERENCE}

[1] HOLANDA, Max. Do CAD ao BIM. Quais as ferramentas do arquiteto brasileiro?. Archdaily, 2019. Disponível em: $<$ https://www.archdaily.com.br/br/914299/do-cad-ao-bim-quais-as-ferramentasdo-arquiteto-brasileiro >. Acesso em: 20 de fev. de 2021.

[2] 9. M.P. Gallaher, A.C. O'Conor, J.L. Dettbarn, L.T. Gilday Cost analysis of inadequate interoperability.. capital facilities industry National Institute of Standards and Technology, Gaithersburg, Maryland, USA (2004), pp. 1-210, 10.6028/NIST.GCR.04-867

[3] FREITAS, Julio Cesar. O que é o BIM?. SPBIM, 2019. Disponível em: <https://spbim.com.br/o-que-e-o-bim/>. Acesso em: 22 de fev. de 2021.

[4] Hamma-adama, Mansur \& Kouider, Tahar. (2019). Comparative Analysis of BIM Adoption Efforts by Developed Countries as Precedent for New Adopter Countries. Current Journal of Applied Science and Technology. 36. 1-25. 10.9734/CJAST/2019/v36i230224.

[5] JR, Francisco Gonçalves. Projetos elétricos em BIM: E agora?.Mais Engenharia, 2017. Disponível em: $<$ https://maisengenharia.altoqi.com.br/bim/projetos-eletricos-em-bim/>. Acesso em: 20 de fev. de 2021.

[6] DA COSTA, Giovani Cecatto Lopes Ribeiro; FIGUEIREDO, Sílvia Haueisen; RIBEIRO, Sidnea Eliane Campos. Estudo comparativo da tecnologia CAD com a tecnologia BIM. Revista de Ensino de Engenharia, v. 34, n. 2, 2015.

[7] NUNESA, G. H.; LEÃO, M. Estudo comparativo de ferramentas de projetos entre o CAD tradicional e a modelagem BIM Comparative study of design toolsthe traditional CAD and BIM modeling. Revista de Engenharia, v. 155, n. 55, p. 47-61, 2018.

[8] DE SOUZA, Derek Santos et al. ANÁLISE COMPARATIVA DAS PLATAFORMAS BIM E CAD NA APLICAÇÃO DE PROJETOS DE EDIFICAÇÕES. Epitaya E-books, v. 1, n. 5, p. 343-358, 2020.

[9] Uso de BIM pode reduzir até $20 \%$ de custos na construção, o dobro previsto pelo governo. INFRAROI, 2019. Disponível em: <https://url.gratis/gjKwA > Acesso em: 20 de fev. de 2021.

[10] SALABERRY, Cícero Rodrigues. Os impactos do BIM para redução de custos da obra. Ambar, 2019. Disponível em: <https://www.ambar.tech/os-impactos-dobim-para-reducao-de-custos-da-obra/>. Acesso em: 22 de fev. de 2021. 